\title{
The Use of Vibra Engine to Enhance Batako Industrial Quality at Urban Area
}

\author{
Author \\ Totok Dwi Kuryanto, Irawati, Nanang Saiful Rizal \\ Correspondence \\ Teknik Sipil, Fakultas Teknik, Universitas Muhammadiyah Jember \\ Email: totok_dk@yahoo.co.id, rizal.nanang@yahoo.co.id
}

\begin{abstract}
The main objective of the Technology for the Society ( $\mathrm{IbM}$ ) is aimed at addressing the main problems faced by approximately 200 urban poor, namely: (1) The location of the residence located on the edge of the city with a distance society of about $10 \mathrm{~km}$ from urban areas. (2) Low economic level or low income about Rp.600.000 / month so it can not meet the basic needs and lift the economy of the surrounding community. The specific target in this IbM program is to apply Batako engine utilization technology to improve the quality and quantity of local Batako production of marginalized urban communities which originally produced only Batako blocks of about 200 seeds to 1000 seeds per day and increased concrete compressive strength. from $175 \mathrm{Kg} / \mathrm{cm} 2$ to $225 \mathrm{Kg} / \mathrm{cm} 2$, thereby increasing employment for the surrounding communities and increasing the income of business actors and partner workers. The method of implementation to solve the problems of the program partners of IbM is to increase the added value of community income through the utilization of Batako chili type which includes the stages: (a) The socialization of Batako IbM program; (b) Preparing social prerequisites, such as strengthening rural community groups, groups and forums as a medium to meet and solve problems faced by farmers or the poor; (c) Implementation of Batako IbM program, supported by related institutions (Dinas Cipta Karya Kabupaten Lumajang and University (Faculty of Engineering, Muhammadiyah University of Jember), and (d) Monitoring, evaluation and reporting.
\end{abstract}

Keywords: Batako, block, community, periphery, urban

Received: 15 December 2017. Accepted: 15 January 2018

\section{Introduction}

From 2000 to 2012 Batako's current utilization has increased quite sharply, most of which are widely used as road insurance both in urban and residential environments. It happens because the Batako has many advantages compared to asphalt such as relatively cheap price, easy implementation does not require heavy equipment, maintenance cost and maintenance is quite easy, and the quality can be controlled easily. Through the cooperation between the District Government, Small Industrial Center can be done to provide benefits for the welfare of the small industry community of the Batako.

Economic development in the suburbs will reduce the occurrence of urbanization, criminal acts so that the suburbs will remain an economic buffer zone that has the function of improving people economy (Dinas Koperasi Kabupaten Lumajang, 2006). The community of small industrial centers in the suburbs of Lumajang Regency located in Klakah and Kedungjajang Sub- districts for several years developed a small industrial center of Batako, paving blocks, concrete roof tiles and concrete door frames are facing the problem of low quality of Batako that has not reached Indonesian standards so that the selling price and low demand. The quality quality of Batako that does not yet have a good standard of production is related to raw material mixing techniques, processing techniques, so that on average every micro-enterprise can only sell Batakoblocks of about 2000 pieces per week. The price ranges from $\mathrm{Rp} 2000$ - Rp 2500 per seed. If the quality of Batako according to standard and very good, then the market demand is increasing, and the price can reach $\mathrm{Rp} 3000$ per seed.

Based on the description above the low quality of Batako resulted in the decrease of Batako demand and tend to consumers choose Batako production from the rather large industry setra (Nanang, 2010 and 2011). This situation is exacerbated by the increased production of Batako 
from large industrial centers of excellent quality (Http: // www. Geocities.com, 2011).

The small industrial district in the suburbs of Lumajang Regency keeps developing simple technology because of limited capital, equipment, knowledge, management and skills. Another reason, because the only business is only run to sustain household needs. The problem of low quality of Batako is a complaint of small business actors, and in the long run if left unchecked will disrupt the economy of micro business actors, there are many employee's termination and the community will return urbanization to the city that trigger the occurrence of crime and crime in urban areas. Based on that fact, the Faculty of Engineering of Muhammadiyah University of Jember in coordination with the Local Government of Jember Regency (Bappekab Lumajang Regency) will cooperate with the SMEs of the village community in Kedungjajang and Klakah Sub-districts in the Community Science Science (ICT) program in 2017.

\section{Partner Problems}

The community groups in Klakah and Kedungjajang sub-districts of Lumajang have an average complaint about the lack of income, one of which is because the business has no productivity. People in these two villages survive because of their commitment ti live in their village where they were born who have for years contributed greatly to their family's income.

The results of previous observations by Nanang et al. (2010) claimed that the problem of income shortage can be addressed by doing efficiency while utilizing the existing natural potency to make money at science and technology activity location in Klakah and Kedungjajang sub-district, Lumajang Regency, they are:

a. The occurrence of increased cost of living one of them caused the increase in the price of basic needs that must be imported from outside the region.

b. The absence of institutions (both groups and forums) in the community that organize and contribute to increase the income of the community.

c. The lack of potential mapping from the local government of Lumajang Regency and related offices on the village community in the hills area about the abundant raw material potential.

\section{Activity Impacts}

The impact of this activity is to increase the quality and quantity of Batako production blocks of urban suburbs and the improvement of the surrounding community's economy.

\section{Activity Output}

The type of output that will be generated in the $\mathrm{IbM}$ program is a product of dissemination of appropriate technology to manufacture Batako to increase both the quantity and quality of Batako

\section{PHASE OF ACTIVITY \\ IbM Coordination Activities}

The coordination activities of IBM Muhammadiyah University of Jember which has been done with the community/target group includes:

- Coordination with IbM program target candidate is Batako business group in Lumajang District.

- Coordinate with prospective Partners in Lumajang District.

- Preparation of IbM program with the community and the Village Government, which includes determining the schedule and execution of activities:

a. Counseling of Batako efforts and sharing experiences with business groups

b. Administrative and accounting education and business management of Batako

c. Batako business technology extension

d. Training and sharing of Batako business management improvements

e. Training and sharing of Batako's more efficient and profitable business technology improvements.

f. Assistance and activation of Batako business group discussions.

g. Mentoring and marketing business networking of Batako with Partners and Government.

\section{Training Activities}

IbM Training by IbM Implementation Team Muhammadiyah University of Jember conducted for 1 day with the core material: 
1. IbM implementation scheme

2. Preparation of materials.

3. Printing Process.

4. Drying Process and Marketing System

5. Material Detail Description :

a. Selection of materials, namely the determination of material quality standards that include sand and cement. The sand selected is sand with mud content up to $3 \%$. Then the cement selected is a cement with SNI standard.

b. Water, selected water that contains no acid and other chemicals.

c. Mixer is a mixing process of sand, water and cement. The composition is used in accordance with the results of job mix conducted in the Laboratory of Civil Engineering University of Muhammadiyah Jember.

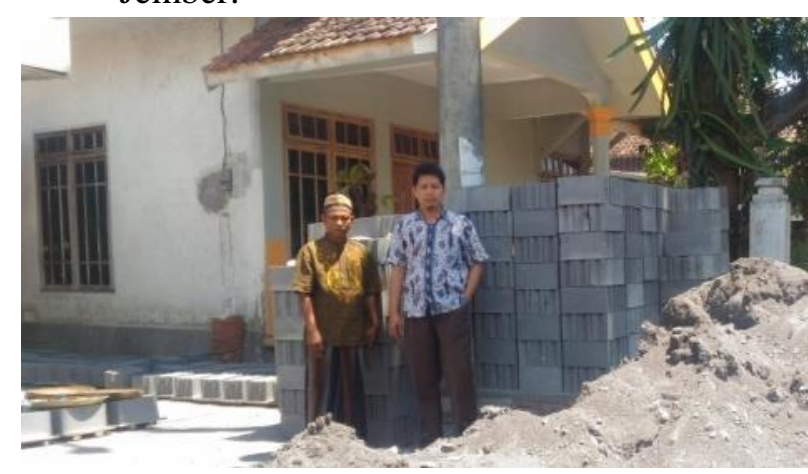

Figure 1. Drying process and Batako production

\section{Business Assistance}

Assistance is done so that activities can take place in a sustainable manner are as follows :

1. Counseling and coordination in the Batako craftsmen group

2. Training and sharing of the true Batako business to the craftsmen group

3. Assistance to the group of craftsmen in order to increase the quality and quantity of Batako production.

4. Ongoing evaluation of progress made.

\section{Implementation of IbM Activities}

\section{Implementation of IbM Activities Covers :}

a. Preparation of institutional or Business Group Batako

- Institutional arrangements are made to facilitate the development of business in groups, because business assistance will be given in groups.
- The result of coordination with all Batako makers, was obtained by two business groups of Batako which further assistance will be given to 2 business groups that will be managed together.

\section{Counseling, Business Sharing and Drafting of MoU}

- Batako business extension is conducted to all members of Batako business group including business development by utilizing Batako engine type vibra technology

- Receive complaints, suggestions related to Batako business development at IbM site

- Plan of preparation for the handover of aid by preparing $\mathrm{MoU}$ for cooperation between business group, village head and Muhammadiyah University of Jember. In the long run for a series of IbM Programs University of Muhammadiyah Jember in a particular theme that will be implemented on an ongoing basis will realize the achievement of the results of the increase in community empowerment measurably in the form of increased income per capita.

\section{RESULT OF ACTIVITY}

a. Batako Machine Assistance Submission and Signing MoU

- The submission of Batako's machine assistance was carried out to all 2 Batako business groups. The assistance consists of 2 Batako type vibra machine capacity 2 Batako per press and 2 pieces of diesel engine driving 7 PK Don Feng.

- Submission of Batako machine followed up with MoU signing between University of Muhammadiyah Jember with Business Group and the Head of Village in Lumajang Regency. The purpose of signing the MoU is.:

1. To get legalization of assistance to business groups

2. To ensure that the BATAKO machine is truly beneficial to the group and all members. 


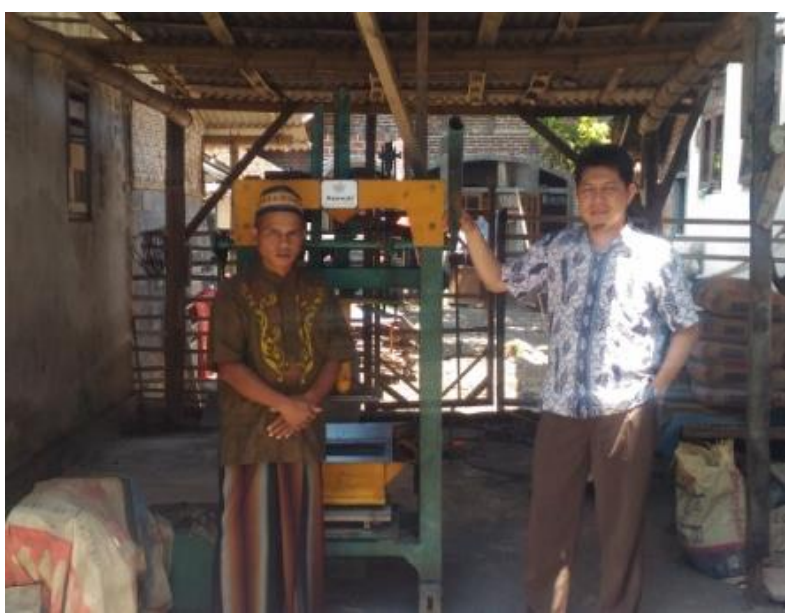

Figure 2. Batako machine handover to party-1

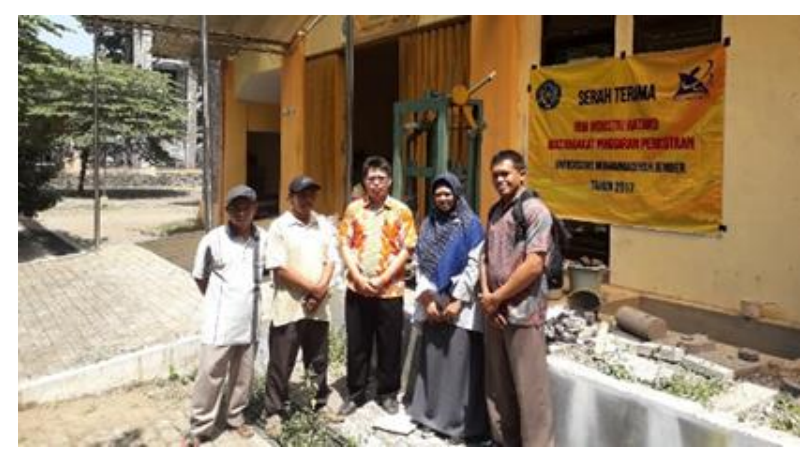

Figure 3. Batako machine hand over to party-2

\section{b. Training on the Use of Batako Tools and Product Creation}

- The training includes the following:

1. Material selection and materials storage techniques

2. Introduction of Batako models, their advantages and disadvantages.

3. Introduction of a simple or manual process in the manufacture of Batako.

4. Introduction of Batako making process using Batako type vibra engine

5. Introduction of tools and mode of operation of Batako engine of vibra type.

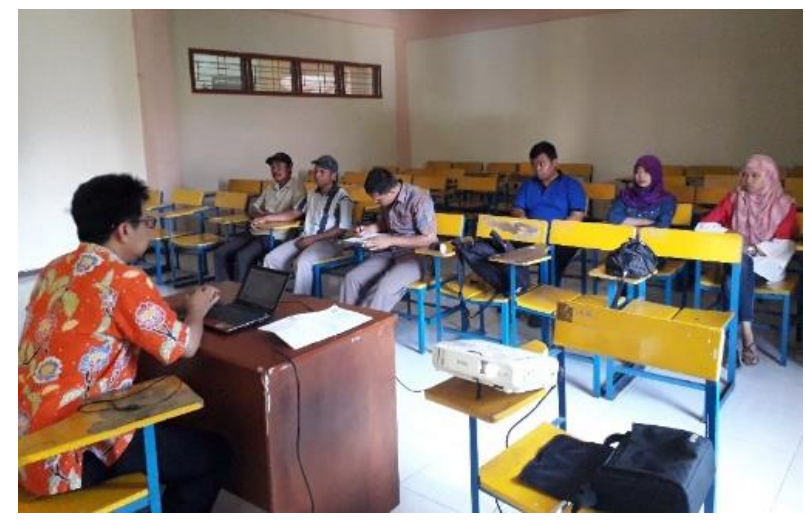

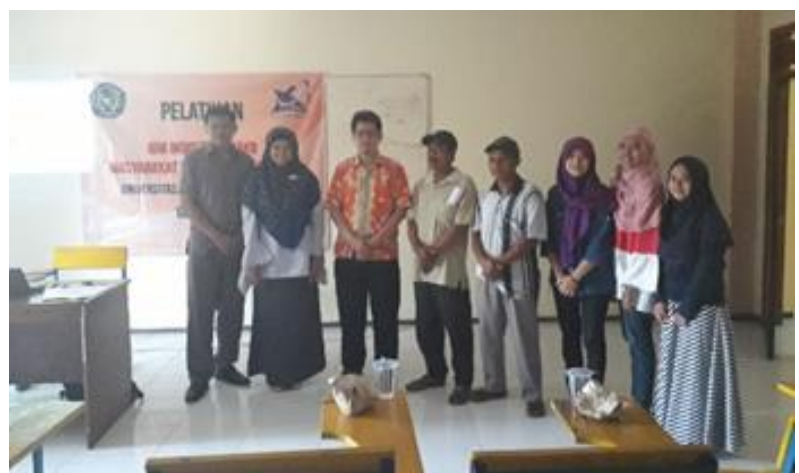

Figure 4. Batako business training

\section{c. Batako Production Trial}

After the training the use of tools continued with the manufacture of samples of Batako products. To make an example of implementing IbM facilitate by buying 1 Pick Up Sand, 6 PC Cement Fruits. After the obtained Batako of 200 Fruits.

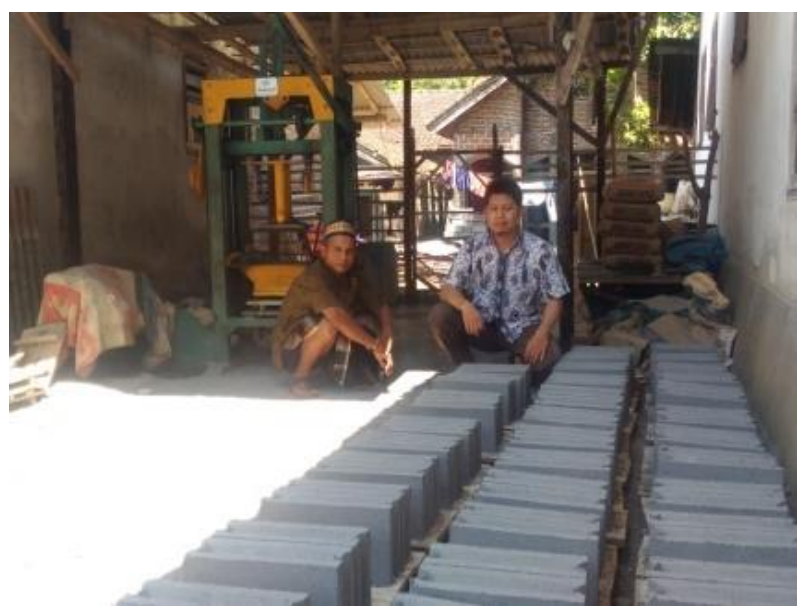

Figure 5. Batako block testing

\section{d. Batako Quality Test Block}

- The Batako quality test is conducted to ensure that the Batako produced meets Indonesian National Standard (SNI).

- To conduct Batako quality test, 10 samples of Batako were taken and then tested in Civil Engineering Laboratory of Muhammadiyah University of Jember.

- The results obtained show that the Batako blocks obtained meet the SNI quality standards. 


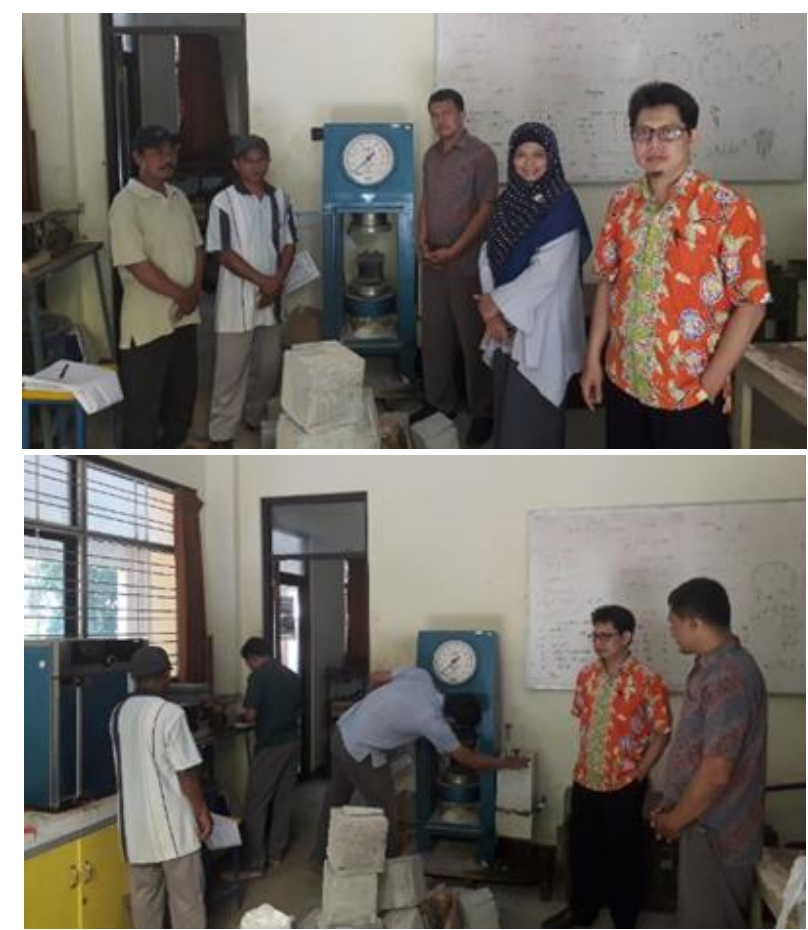

Figure 6. Batako laboratory testing

\section{e. Production Marketing Assistance Batako}

- Marketing assistance is carried out by the implementers and students and lecturers of the Field by way of: making company profile of business group, coordinating with Batako user stakeholders such as: Construction Association (Gapensi, Gapeknas) and Dinas Cipta Karya Kabupaten Lumajang.

- The results show that related agencies and Construction Associations give appreciation to business development by Batako business group built by Muhammadiyah University of Jember in Batako Program.

\section{CONCLUSION}

The conclusion that have been obtained in this IbM activity are as follows:

1. Stages of the implementation of IbM has been in accordance with the work programs that have been prepared. Implementation of IbM includes the socialization of IbM program, delivery of Batako vibra machine assistance, business management training and up to mentoring the marketing of Batako products obtained by all business groups

2. Implementation of $\mathrm{IbM}$ program has contributed to business groups in business development and quality improvement and quantity of Batako blocks in Lumajang District.

The suggestions that can be described in IbM activities are as follows:

1. Need more intense coordination between the business groups so that business group activities can be better.

2. Assistance to business groups by relevant agencies is increasing and expected to be sustainable in the future.

\section{References}

Anonim. 2012. Survei Potensi Ekonomi Masyarakat Pedesaan. LPPM, Universitas Muhammadiyah Jember.

Anonim. 2010. Petunjuk Penggunaan Mesin BATAKO Tipe Vibra, Toko Bin Madi Surabaya Anonim. 2012. Panduan Pembuatan BATAKO. LPPM, Universitas Muhammadiyah Jember. BPS Lumajang, 2011, Lumajang dalam Angka. Kantor Kecamatan Yosowilangun. 2012. Laporan Tahunan Kecamatan. Kabupaten Lumajang. 